\title{
Disturbance of Cerebral Oxygenation and Hemodynamics Related to the Opening of the Bypass Bridge during Veno-Arterial Extra- corporeal Membrane Oxygenation ${ }^{1}$
}

\author{
K. D. LIEM, L. A. A. KOLlÉE, J. H. G. M. KLAESSENS, W. B. GEVEN, C. FESTEN,
} A. F. J. DE HAAN, AND B. OESEBURG

\begin{abstract}
ECMO Research Group, Department of Pediatrics [K.D.L., L.A.A.K, J.H.G.M.K., W.B.G.], Pediatric Surgery [C.F.], Medical Statistics [A.F.J.D.H.], and Physiology [B.O.], University Hospital and Faculty of Medical Sciences, University of Nijmegen, Nijmegen, The Netherlands
\end{abstract}

\begin{abstract}
The objective of this study was to investigate changes of cerebral oxygenation and hemodynamics related to opening of the bypass bridge during veno-arterial extracorporeal membrane oxygenation (ECMO). Ten newborn infants and 12 piglets were studied during opening of the bridge for 10 and $1 \mathrm{~s}$, respectively. Changes in cerebral concentration of oxyhemoglobin $\left(c \mathrm{O}_{2} \mathrm{Hb}\right)$, deoxyhemoglobin $(\mathrm{cHHb})$, (oxidized-reduced) cytochrome $\mathrm{aa}_{3}$ $\left(c \mathrm{Cyt} . \mathrm{aa}_{3}\right)$, and blood volume (CBV) were continuously measured by near infrared spectrophotometry. Heart rate, arterial $\mathrm{O}_{2}$ saturation $\left(\mathrm{saO}_{2}\right)$, and mean arterial blood pressure (MABP) were measured simultaneously. In the piglets, central venous pressure (CVP), intracranial pressure (ICP), and left common carotid artery blood flow $(\mathrm{CaBF})$ were also measured. Opening of the bridge for $10 \mathrm{~s}$ in the infants resulted in a significant decrease in $\mathrm{MABP}, s \mathrm{aO}_{2}$, and $c \mathrm{O}_{2} \mathrm{Hb}$, whereas $c \mathrm{HHb}$ increased. $\mathrm{CBV}$ did not change significantly. In piglets biphasic changes were observed for $\mathrm{MABP}, \mathrm{CaBF}, \mathrm{O}_{2} \mathrm{Hb}$, and $\mathrm{CBV}$, showing an initial decrease followed by a smaller increase. $c \mathrm{HHb}$ and CVP showed reverse biphasic changes. ICP increased but $\mathrm{saO}_{2}$ was unchanged. In all cases heart rate and $c \mathrm{Cyt}_{\mathrm{aa}}$ did not change significantly. Opening of the bridge for $1 \mathrm{~s}$ resulted in minor changes in only a few variables. In conclusion, opening of the
\end{abstract}

\section{ABSTRACT}

bridge resulted in a decrease of $\mathrm{CBV}$ and cerebral $\mathrm{O}_{2}$ supply due to a decrease of cerebral blood flow, followed by a compensatory increase of cerebral $\mathrm{O}_{2}$ extraction and vasodilatation. The return of oxygenated blood after reclosing resulted in an increase of $\mathrm{CBV}$ with overcompensation of cerebral $\mathrm{O}_{2}$ supply. (Pediatr Res 38: 124-129, 1995)

\section{Abbreviations}

ECMO, extracorporeal membrane oxygenation

NIRS, near infrared spectrophotometry

$c \mathrm{O}_{2} \mathbf{H b}$, oxyhemoglobin concentration ${ }^{2}$

$c \mathbf{H H b}$, deoxyhemoglobin concentration ${ }^{2}$

ctHb, total Hb concentration ${ }^{2}$

$c$ Cyt.aa ${ }_{3}$, (oxidized-reduced) cytochrome aa ${ }_{3}$ concentration

CBV, cerebral blood volume

CBF, cerebral blood flow

CaBF, mean carotid blood flow

$\mathrm{saO}_{2}$, arterial $\mathrm{O}_{2}$ saturation

MABP, mean arterial blood pressure

CVP, central venous pressure

ICP, intracranial pressure
ECMO improves the survival rate of newborn infants with severe respiratory failure, who do not respond to conventional treatment $(1,2)$. In many short-term follow up studies the handicap rate among survivors was reported to be about $20 \%$

Received June 30, 1994; accepted March 9, 1995.

Correspondence: K. D. Liem, Department of Pediatrics, University Hospital Nijmegen, P.O. Box 9101, 6500 HB Nijmegen, The Netherlands.

Supported in part by a Prinses Beatrix Fonds Grant 92.132.

1 Part of this work has been presented at the meeting of European Society for Paediatric Research, Paediatric Week Holland 1994, Rotterdam, The Netherlands, July 1994.

${ }^{2}$ According to the guidelines of the U.S. National Committee for Clinical Laboratory Standards (NCCLS), Document C25-P, Vol. 10, No. 2, 1990.
$(3,4)$. Cerebrovascular injury is one of the important predictors of poor neurodevelopmental outcome (3).

In the ECMO circuit a bypass bridge is placed between the arterial and the venous tubing to allow continuation of blood circulation in the ECMO system during an emergency when the patient is taken off ECMO by clamping both cannulae $(5,6)$. During the ECMO run, the bridge is clamped, but to prevent clot formation from prolonged blood stasis in the bridge, brief opening of the bridge every $15 \mathrm{~min}$ is part of routine management. However, opening of the bridge results in arterial-venous shunting in the ECMO circuit which might disturb the blood circulation 
and $\mathrm{O}_{2}$ supply to the brain. Using NIRS, the influence of bypass bridge opening on cerebral oxygenation and hemodynamics was investigated in newborn infants and in piglets.

\section{METHODS}

Newborn infants. Ten newborn infants (gestational age, 35.1-41.6 wk; birth weight, $2100-4330 \mathrm{~g}$; eight boys and two girls) who required ECMO treatment were studied after informed parental consent was given. The study was approved by the University Hospital ethics committee. All infants met the established ECMO selection criteria (1), which include cerebral ultrasound investigation. So, infants with cerebral hemorrhage or cerebral malformation would have been excluded. The underlying diseases were congenital diaphragmatic hernia $(n=$ 4), meconium aspiration syndrome $(n=2)$, and persistent pulmonary hypertension due to other causes $(n=4)$. Before cannulation the infants were anesthetized using Fentanyl (0.01 $\mathrm{mg} / \mathrm{kg}$ ) (Janssen, Tilburg, The Netherlands) and midazolam $(0.1 \mathrm{mg} / \mathrm{kg})$. All infants were already paralyzed with pancuronium $(0.01-0.02 \mathrm{mg} / \mathrm{kg} / \mathrm{h})$ and treated with vasoactive drugs (dopamine and/or dobutamine, 5-10 $\mu \mathrm{g} / \mathrm{kg} / \mathrm{h}$ ). During ECMO the infants were mechanically ventilated (Babylog 8000, Dräger, Lübeck, Germany) at a low level for pressure (20-25 mbar), rate (16 breaths/min), and inspiratory $\mathrm{O}_{2}$ fraction $(0.30)$. Medication prescribed before ECMO was continued during the measurement period.

Heart rate and (umbilical) MABP were continuously monitored (Sirecust 404N, Siemens, Erlangen, Germany). Foot arterial $\mathrm{O}_{2}$ saturation $\left(\mathrm{saO}_{2}\right)$ was also continuously measured by pulse oximetry (N 200, Nellcor Inc., Hayward, CA).

Piglets. Twelve female piglets (age $2-3 \mathrm{wk}$, weight 7.6-8.5 $\mathrm{kg}$ ) were obtained from a local farm. The piglet was selected as the animal model because of its closer physiologic resemblance to the human infant, easy availability, and low cost (7). For sedation, a mixture of droperidol and Fentanyl $(0.25 \mathrm{mg} / \mathrm{kg}$ and $0.005 \mathrm{mg} / \mathrm{kg}$, respectively) was administered intramuscularly. After $30 \mathrm{~min}$ anesthesia was induced by i.v. midazolam (1.5 $\mathrm{mg} / \mathrm{kg})$, atropine $(0,25 \mathrm{mg})$, and Fentanyl $(0.2 \mathrm{mg} / \mathrm{kg})$. During artificial ventilation (Babylog 8000 , Dräger), anesthesia was maintained using i.v. Fentanyl $(0.2 \mathrm{mg} / \mathrm{kg} / \mathrm{h})$, midazolam $(0.4$ $\mathrm{mg} / \mathrm{kg} / \mathrm{h})$, and droperidol $(0.1 \mathrm{mg} / \mathrm{kg} / \mathrm{h})$. The piglets were paralyzed with pancuronium (loading dose $0.2 \mathrm{mg} / \mathrm{kg}$, maintaining dose $0.15 \mathrm{mg} / \mathrm{kg} / \mathrm{h}$ ). The ventilator settings were adjusted to maintain $p \mathrm{aCO}_{2}$ between 30 and $40 \mathrm{~mm} \mathrm{Hg}(4-5.3$ $\mathrm{kPa})$ and $\mathrm{paO}_{2}$ between 75 and $100 \mathrm{~mm} \mathrm{Hg}(10-13.3 \mathrm{kPa})$. Rectal temperature was monitored and maintained between 38 and $39^{\circ} \mathrm{C}$ with a servo-controlled heating mattress.

Catheters were placed in the abdominal aorta through a femoral artery and in the inferior vena cava near the right atrium via a femoral vein for continuous monitoring of MABP (HP 78206C, Hewlett Packard, Boeblingen, Germany) and CVP (HP 78205C, Hewlett Packard, Boeblingen, Germany). Through the other femoral artery a fiberoptic oximeter catheter (Spectracath STP 7.5 F, Viggo Spectramed, Oxnard, CA) was inserted into the abdominal aorta for on-line continuous monitoring of $\mathrm{saO}_{2}\left(\mathrm{HemoprO}_{2} \mathrm{SP} 1455\right.$, Viggo Spectramed, Oxnard, CA). Mean blood flow in the left common carotid artery
$(\mathrm{CaBF})$ was continuously recorded by an electromagnetic flowmeter (Scalar MDL 1401, Scalar Medical, Delft, The Netherlands) using a $2.5-\mathrm{mm}$ diameter probe. Changes in $\mathrm{CaBF}$ reflect changes in CBF (8). After neck incision the cisterna magna were punctured with a hollow needle through the foramen magnum, and a catheter was placed through the needle into the cisterna magna for continuous monitoring of ICP (HP 78205C, Hewlett Packard, Boeblingen, Germany). The needle was withdrawn after successful positioning of the catheter, as shown by a pulsatile signal on the monitor.

Six piglets were put on ECMO during normoxemic condition. The other six piglets were put on ECMO after being hypoxemic $\left(\mathrm{saO}_{2}<80 \%\right)$ for at least $2 \mathrm{~h}$ due to ventilator $\mathrm{FiO}_{2}$ between 0.16 and 0.18 .

NIRS. The NIRS equipment used was developed by the Department of Biomedical Engineering and Medical Physics, University of Keele (UK) and produced by Radiometer (Copenhagen, Denmark) (9). This method is based on spectrophotometric measurement of changes in the absorption properties of $\mathrm{Hb}$ and cytochrome $\mathrm{aa}_{3}$ in the near infrared region, depending on their oxygenation state (10). Details of our NIRS measurement procedure have been described earlier (11). Briefly, near infrared light at three wavelengths $(904,845$, and $775 \mathrm{~nm}$ ) was transmitted through the skull by fiberoptic bundles. Using the described algorithm, concentration changes of oxyhemoglobin $\left(\Delta c \mathrm{O}_{2} \mathrm{Hb}\right)$, deoxyhemoglobin $(\Delta c \mathrm{HHb})$, and (oxidized-reduced) cytochrome $\left.\mathrm{aa}_{3}\left(\Delta c \mathrm{Cyt}_{\mathrm{aa}}\right)_{3}\right)$ were calculated from changes in absorption of near infrared light at these three wavelengths. The transmitting and receiving optodes were fixed to the skull as previously described (12). In the infants they were placed at a relative angle of approximately $90^{\circ}$, one at the anterior fontanelle, the other at the right parieto-temporal region. In piglets each optode was positioned between the midline of the skull and the ear. Interoptode spacing was $>2.5 \mathrm{~cm}$, to ensure a constant path length multiplying factor (13), which has been stated to be 4.39 times the interoptode spacing (14). As the optical path length is wavelength-dependent, some modification of the algorithm has been made (15). Using the obtained optical path length and a value of 1.05 for brain-specific mass, the concentration changes are expressed in micromoles $/ 100$ g. $\Delta c \mathrm{O}_{2} \mathrm{Hb}$ and $\Delta c \mathrm{HHb}$ reflect changes in cerebral $\mathrm{O}_{2}$ supply, whereas $\Delta c$ Cyt.aa $a_{3}$ reflects changes in cerebral $\mathrm{O}_{2}$ availability (16). Changes in concentration of total $\mathrm{Hb}(\Delta c \mathrm{tHb})$ were calculated as the sum of $\Delta c \mathrm{O}_{2} \mathrm{Hb}$ and $\Delta c \mathrm{HHb}$. Changes in cerebral blood volume $(\triangle \mathrm{CBV})$, expressed in milliliters $/ 100 \mathrm{~g}$, were calculated from the formula $\Delta \mathrm{CBV}=(4 \cdot \Delta c \mathrm{tHb}) /(0.69 \cdot c \mathrm{Hb})$, where $c \mathrm{Hb}=$ arterial $\mathrm{Hb}$ concentration in millimoles $/ \mathrm{L}, 0.69=$ cerebralarterial hematocrit ratio (17), and $4=$ correction factor, because $c$ tHb is calculated from changes in light absorption using extinction coefficient based on the tetraheme molecule, whereas $c \mathrm{Hb}$ determination is based on the monoheme molecule.

Experimental procedure. After cannulation of the right common carotid artery and the internal jugular vein (in piglets the external jugular vein was used) standard veno-arterial ECMO was performed (1). After starting ECMO the flow rate was increased gradually over several minutes until a level (ranging from 140 to $205 \mathrm{~mL} / \mathrm{kg} / \mathrm{h}$ in the infants and from 65 
to $100 \mathrm{~mL} / \mathrm{kg} / \mathrm{h}$ in the piglets) was reached, which was sufficient to maintain $\mathrm{saO}_{2}$ between 95 and $100 \%$. Approximately $1 \mathrm{~h}$ after the start of ECMO and stabilization of all variables, the bypass bridge was opened for $10 \mathrm{~s}$. After restabilization of the measured variables, the bypass bridge was opened again for just $1 \mathrm{~s}$, because in current clinical practice the period during which the bridge is opened ranges from 1 to $10 \mathrm{~s}$. Due to expected changes in cerebral oxygenation and hemodynamics, a longer opening time than $10 \mathrm{~s}$ might expose the newborn to unnecessary risk. To imitate the clinical situation we used the same opening time of the bridge in the piglets and did not wait till a steady state was reached during opening of the bridge. During the experiments all variables were measured by a sampling rate of $1 \mathrm{~Hz}$. Due to technical problems, the data of a 1-s bridge opening in one piglet were not available. Measurement of $\mathrm{CaBF}$ failed in another piglet.

Data analysis. Before analysis, the data of CVP and ICP were filtered with a $0.3-\mathrm{Hz}$ low pass filter to reduce signal noise caused by breathing movements. For each variable the mean and SD value were calculated from a 30 -s period before opening of the bypass bridge. The beginning of MABP change was considered to represent the actual beginning of the bridge opening $(t=0)$. The mean values were the base levels for the corresponding signal. The analysis searched for the first minimum and maximum change within $120 \mathrm{~s}$. The search for the first minimum started if the signal exceeded the base level more than $-2 \mathrm{SD}$ for more than $3 \mathrm{~s}$ and continued until the signal exceeded a level more than 2 SD above the local minimum for more than $3 \mathrm{~s}$. The first maximum was found in a similar way. Minimum and maximum changes were calculated as the difference between this local minimum or maximum and its base level. When no peak change was found a value of zero was taken. The results were statistically analyzed by performing the Wilcoxon signed rank test and the level of significance was chosen at 0.01 to correct for multiple testing (Bonferoni correction).

\section{RESULTS}

Newborn infants. Recording of important variables in an infant during opening of the bridge for $10 \mathrm{~s}$ is shown in Figure 1. The results of the calculation are presented in Tables 1 and 2. Opening of the bypass bridge for $10 \mathrm{~s}$ was followed by a significant decrease in $\mathrm{MABP}, c \mathrm{O}_{2} \mathrm{Hb}$, and $s \mathrm{O}_{2}$ and an increase in $c \mathrm{HHb}$. $\mathrm{CBV}$ showed changes suggestive of a biphasic course, showing an initial decrease followed by a secondary increase, but these changes were not large enough to reach statistical significance. The peak change of the NIRS variables occurred at the same time interval as that of MABP. The negative peak change of $\mathrm{saO}_{2}$ occurred after that of MABP. After opening of the bridge for $1 \mathrm{~s}$, only a significant decrease of $c \mathrm{O}_{2} \mathrm{Hb}$ and $\mathrm{MABP}$ and a increase of $c \mathrm{HHb}$ were observed. As expected, the values of these peak changes were smaller than after a 10-s opening of the bridge. Heart rate and cCyt.aa were unchanged in both interventions and therefore are not shown in the tables.

Piglets. Recording of important variables in a piglet during opening of the bridge for $10 \mathrm{~s}$ are shown in Figure 2. Inasmuch as there was no significant difference in the response between
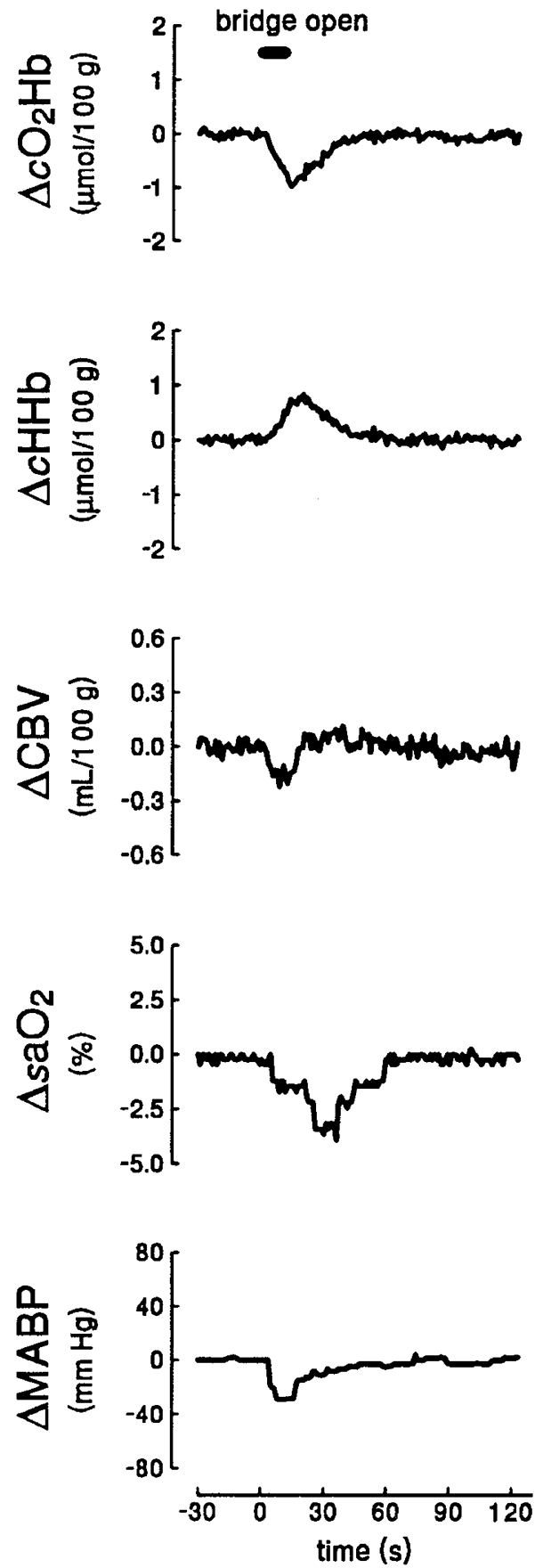

Figure 1. Registration of $c \mathrm{O}_{2} \mathrm{Hb}, c \mathrm{HHb}, c \mathrm{tHb}, s \mathrm{O}_{2}$, and $\mathrm{MABP}$ during opening of the bypass bridge for $10 \mathrm{~s}$ in an infant (sampling frequency, $1 \mathrm{~Hz}$ ).

hypoxemic and normoxemic piglets, they were considered as one group. The response was in the same direction as that in the infant experiment, but the magnitude of the changes was different (Tables 3 and 4). However, a biphasic response after a 10-s opening of the bypass bridge was observed for MABP, $\mathrm{CaBF}, c \mathrm{O}_{2} \mathrm{Hb}$, and $\mathrm{CBV}$, showing an initial decrease followed by a smaller increase. Reverse biphasic response was observed for $c \mathrm{HHb}$ and CVP. The first peak change of these variables occurred at the same time interval. However, the second peak change of $\mathrm{cO}_{2} \mathrm{Hb}$ and $c \mathrm{HHb}$ occurred significantly later than that of CBV. In most piglets ICP showed a biphasic response (Fig. 2). However, only the second (positive) peak change was 
Table 1. Changes during opening of the bypass bridge for $10 \mathrm{~s}$ in 10 infants during ECMO

\begin{tabular}{|c|c|c|c|c|c|}
\hline & $\begin{array}{l}\text { Absolute value } \\
\text { before opening }\end{array}$ & $\begin{array}{l}\text { First peak } \\
\text { change }\end{array}$ & Interval time (s) & $\begin{array}{l}\text { Second peak } \\
\text { change }\end{array}$ & Interval time (s) \\
\hline$\triangle \mathrm{MABP}(\mathrm{mm} \mathrm{Hg})$ & $\begin{array}{c}53.1 \\
(40.0,64.7)\end{array}$ & $\begin{array}{c}-14.5^{*} \\
(-29.1,-2.0)\end{array}$ & $\begin{array}{c}11 \\
(5,15)\end{array}$ & $\begin{array}{c}0.0 \\
(0.0,2.2)\end{array}$ & $\begin{array}{c}64 \\
(42,85)\end{array}$ \\
\hline$\Delta s \mathrm{aO}_{2}(\%)$ & $\begin{array}{c}94.3 \\
(90.9,100.0)\end{array}$ & $\begin{array}{c}-7.9^{*} \\
(-19.8,-3.0)\end{array}$ & $\begin{array}{c}20 \\
(12,36)\end{array}$ & $\begin{array}{c}0.0 \\
(0.0,0.0)\end{array}$ & - \\
\hline$\Delta c \mathrm{O}_{2} \mathrm{Hb}(\mu \mathrm{mol} / 100 \mathrm{~g})$ & Not available & $\begin{array}{c}-0.74^{*} \\
(-1.14,-0.42)\end{array}$ & $\begin{array}{c}14 \\
(11,20)\end{array}$ & $\begin{array}{c}0.04 \\
(0.00,0.33)\end{array}$ & $\begin{array}{c}70 \\
(45,81)\end{array}$ \\
\hline$\Delta c \mathrm{HHb}(\mu \mathrm{mol} / 100 \mathrm{~g})$ & Not available & $\begin{array}{c}0.62^{*} \\
(0.46,1.23)\end{array}$ & $\begin{array}{c}16 \\
(13,22)\end{array}$ & $\begin{array}{c}0.00 \\
(-0.20,0.00)\end{array}$ & $\begin{array}{c}72 \\
(47,88)\end{array}$ \\
\hline$\Delta \mathrm{CBV}(\mathrm{mL} / 100 \mathrm{~g})$ & Not available & $\begin{array}{c}-0.19 \\
(-0.33,0.14)\end{array}$ & $\begin{array}{c}10 \\
(5,21)\end{array}$ & $\begin{array}{c}0.10 \\
(-0.06,0.18)\end{array}$ & $\begin{array}{c}30 \\
(19,108)\end{array}$ \\
\hline
\end{tabular}

Values are median (range).

${ }^{*} p<0.01$.

Table 2. Changes during opening of the bypass bridge for $1 \mathrm{~s}$ in 10 infants during ECMO

\begin{tabular}{|c|c|c|c|c|c|}
\hline & $\begin{array}{l}\text { Absolute value } \\
\text { before opening }\end{array}$ & $\begin{array}{l}\text { First peak } \\
\text { change }\end{array}$ & Interval time (s) & $\begin{array}{l}\text { Second peak } \\
\text { change }\end{array}$ & Interval time (s) \\
\hline$\triangle \mathrm{MABP}(\mathrm{mm} \mathrm{Hg})$ & $\begin{array}{c}54.0 \\
(40.0,74.3)\end{array}$ & $\begin{array}{c}-2.7 \\
(-4.6,-1.8)\end{array}$ & $\begin{array}{c}8 \\
(4,15)\end{array}$ & $\begin{array}{c}0.0 \\
(0.0,0.0)\end{array}$ & - \\
\hline$\Delta s \mathrm{SO}_{2}(\%)$ & $\begin{array}{c}96.8 \\
(89.5,100.0)\end{array}$ & $\begin{array}{c}-0.0 \\
(-3.1,1.5)\end{array}$ & $\begin{array}{c}22 \\
(7,86)\end{array}$ & $\begin{array}{c}0.0 \\
(-1.4,2.0)\end{array}$ & $\begin{array}{c}53 \\
(17,89)\end{array}$ \\
\hline$\Delta c \mathrm{O}_{2} \mathrm{Hb}(\mu \mathrm{mol} / 100 \mathrm{~g})$ & Not available & $\begin{array}{c}-0.11 \\
(-0.16,0.00)\end{array}$ & $\begin{array}{c}7 \\
(3,9)\end{array}$ & $\begin{array}{c}0.05 \\
(0.00,0.23)\end{array}$ & $\begin{array}{c}49 \\
(15,113)\end{array}$ \\
\hline$\Delta c \mathrm{HHb}(\mu \mathrm{mol} / 100 \mathrm{~g})$ & Not available & $\begin{array}{c}0.10 \\
(-0.10,0.13)\end{array}$ & $\begin{array}{c}7 \\
(5,16)\end{array}$ & $\begin{array}{c}0.00 \\
(-0.19,0.00)\end{array}$ & $\begin{array}{c}72 \\
(54,91)\end{array}$ \\
\hline$\triangle \mathrm{CBV}(\mathrm{mL} / 100 \mathrm{~g})$ & Not available & $\begin{array}{c}-0.00 \\
(-0.14,0.12)\end{array}$ & $\begin{array}{c}34 \\
(3,110)\end{array}$ & $\begin{array}{c}0.00 \\
(0.00,0.10)\end{array}$ & $\begin{array}{c}12 \\
(12,12)\end{array}$ \\
\hline
\end{tabular}

Values are median (range).

statistically significant. After opening of the bridge for $1 \mathrm{~s}$, only a single peak change was observed for $c \mathrm{HHb}, \mathrm{CaBF}, \mathrm{MABP}$, and CVP. $s \mathrm{aO}_{2}$, heart rate, and $c$ Cyt.aa ${ }_{3}$ did not change in either intervention. They are not shown in the tables.

\section{DISCUSSION}

We showed that opening of the ECMO bypass bridge results in significant changes in cerebral oxygenation and hemodynamics. Because after a 10 -s opening no steady state occurs, it is impossible to separate the variation in the magnitude of the responses from the rapidity of responses. However, the observed changes can be explained as follows (Fig. 3). Opening of the bridge results in shunting of arterial blood from the oxygenator through the open bypass bridge to the low pressure venous part of the circuit. Because of higher aortic blood pressure, a retrograde blood flow from the arterial cannula into the bypass bridge will occur, resulting in MABP decrease. Simultaneously an initial decrease of CBV was also observed, although this was less clear in the infants. Theoretically a CBV decrease is caused by decreased CBF or increased venous outflow (18). Decreased rather than increased cerebral venous outflow seems to occur, as in piglets CVP increased. Therefore the decrease of CBV can be explained by a larger decrease of $\mathrm{CBF}$ than of cerebral venous outflow. Decreased $\mathrm{CaBF}$ in our piglets reflects also decreased $\mathrm{CBF}(8)$. A positive relationship between CBF and CBV has been described (19). These CBF changes seemed to be related to MABP changes and might be due to disturbed autoregulation during $\operatorname{ECMO}(20,21)$. There
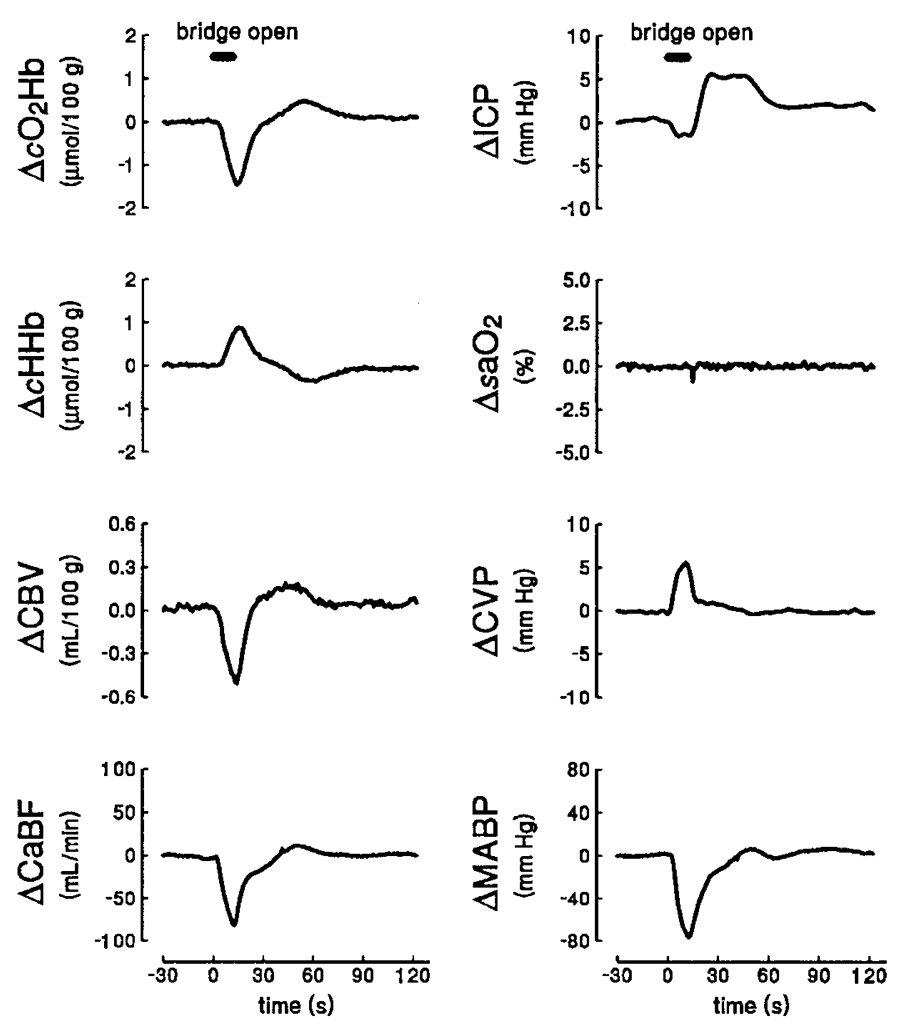

Figure 2. Registration of $\mathrm{cO}_{2} \mathrm{Hb}, c \mathrm{HHb}, c t \mathrm{Hb}, \mathrm{CaBF}, \mathrm{ICP}, \mathrm{CVP}, s \mathrm{O}_{2}$, and $\mathrm{MABP}$ during opening of the bypass bridge for $10 \mathrm{~s}$ in a piglet (sampling frequency, $1 \mathrm{~Hz}$ ). 
LIEM ET AL.

Table 3. Changes during opening of the bypass bridge for $10 \mathrm{~s}$ in 12 piglets during ECMO

\begin{tabular}{|c|c|c|c|c|c|}
\hline & $\begin{array}{l}\text { Absolute value } \\
\text { before opening }\end{array}$ & $\begin{array}{l}\text { First peak } \\
\text { change }\end{array}$ & Interval time (s) & $\begin{array}{l}\text { Second peak } \\
\text { change }\end{array}$ & Interval time (s) \\
\hline$\triangle \mathrm{MABP}(\mathrm{mm} \mathrm{Hg})$ & $\begin{array}{c}113.7 \\
(79.0,135.7)\end{array}$ & $\begin{array}{c}-37.6^{* *} \\
(-76.9,-26.0)\end{array}$ & $\begin{array}{c}12 \\
(9,14)\end{array}$ & $\begin{array}{c}2.5^{*} \\
(0.0,8.9)\end{array}$ & $\begin{array}{c}34 \\
(19,76)\end{array}$ \\
\hline$\Delta \mathrm{CVP}(\mathrm{mm} \mathrm{Hg})$ & $\begin{array}{c}6.7 \\
(4.9,10.5)\end{array}$ & $\begin{array}{r}3.6^{* *} \\
(1.9,7.8)\end{array}$ & $\begin{array}{c}8 \\
(6,14)\end{array}$ & $\begin{array}{c}-0.6^{*} \\
(-1.6,0.0)\end{array}$ & $\begin{array}{c}24 \\
(16,62)\end{array}$ \\
\hline$\Delta s \mathrm{aO}_{2}(\%)$ & $\begin{array}{c}99.3 \\
(86.1,99.4)\end{array}$ & $\begin{array}{c}0.0 \\
(-2.9,1.7)\end{array}$ & $\begin{array}{c}16 \\
(8,39)\end{array}$ & $\begin{array}{c}0.0 \\
(-6.3,0.0)\end{array}$ & $\begin{array}{c}28 \\
(22,33)\end{array}$ \\
\hline$\triangle \mathrm{ICP}(\mathrm{mm} \mathrm{Hg})$ & $\begin{array}{c}16.0 \\
(10.5,21.2)\end{array}$ & $\begin{array}{c}-1.8 \\
(-4.1,2.8)\end{array}$ & $\begin{array}{c}7 \\
(4,14)\end{array}$ & $\begin{array}{c}4.7^{*} \\
(-0.8,12.5)\end{array}$ & $\begin{array}{c}19 \\
(12,80)\end{array}$ \\
\hline$\Delta \mathrm{CaBF} \dagger(\mathrm{mL} / \mathrm{min})$ & $\begin{array}{c}123.8 \\
(92.2,200.7)\end{array}$ & $\begin{array}{c}-37.3^{* *} \\
(-80.3,-30.8)\end{array}$ & $\begin{array}{c}11 \\
(9,13)\end{array}$ & $\begin{array}{c}8.2^{*} \\
(0.0,18.9)\end{array}$ & $\begin{array}{c}24 \\
(19,50)\end{array}$ \\
\hline$\Delta c \mathrm{O}_{2} \mathrm{Hb}(\mu \mathrm{mol} / 100 \mathrm{~g})$ & Not available & $\begin{array}{c}-0.65^{* *} \\
(-1.48,-0.42)\end{array}$ & $\begin{array}{c}12 \\
(7,22)\end{array}$ & $\begin{array}{c}0.16^{* *} \\
(0.00,0.50)\end{array}$ & $\begin{array}{c}53 \\
(15,68)\end{array}$ \\
\hline$\Delta c \mathrm{HHb}(\mu \mathrm{mol} / 100 \mathrm{~g})$ & Not available & $\begin{array}{c}0.50^{* *} \\
(0.24,0.87)\end{array}$ & $\begin{array}{c}13 \\
(9,22)\end{array}$ & $\begin{array}{c}-0.14^{*} \\
(-0.37,0.00)\end{array}$ & $\begin{array}{c}60 \\
(53,68)\end{array}$ \\
\hline$\Delta \mathrm{CBV}(\mathrm{mL} / 100 \mathrm{~g})$ & Not available & $\begin{array}{c}-0.24 * * \\
(-0.52,-0.14)\end{array}$ & $\begin{array}{c}10 \\
(7,14)\end{array}$ & $\begin{array}{c}0.13^{* *} \\
(0.06,0.22)\end{array}$ & $\begin{array}{c}20 \\
(15,51)\end{array}$ \\
\hline
\end{tabular}

Values are median (range).

$* p<0.01$.

$* * p<0.001$.

$\dagger n=11$.

Table 4. Changes during opening of the bypass bridge for $1 \mathrm{~s}$ in 11 piglets during ECMO

\begin{tabular}{|c|c|c|c|c|c|}
\hline & $\begin{array}{l}\text { Absolute value } \\
\text { before opening }\end{array}$ & $\begin{array}{l}\text { First peak } \\
\text { change }\end{array}$ & Interval time (s) & $\begin{array}{l}\text { Second peak } \\
\text { change }\end{array}$ & Interval time (s) \\
\hline$\triangle \mathrm{MABP}(\mathrm{mm} \mathrm{Hg})$ & $\begin{array}{c}105.6 \\
(69.2,127.9)\end{array}$ & $\begin{array}{c}-11.7^{* *} \\
(-16.9,-6.7)\end{array}$ & $\begin{array}{c}5 \\
(5,7)\end{array}$ & $\begin{array}{c}2.0 \\
(0.0,3.6)\end{array}$ & $\begin{array}{c}35 \\
(14,87)\end{array}$ \\
\hline$\Delta \mathrm{CVP}(\mathrm{mm} \mathrm{Hg})$ & $\begin{array}{c}6.4 \\
(4.7,11.1)\end{array}$ & $\begin{array}{c}0.9^{*} \\
(-0.8,2.1)\end{array}$ & $\begin{array}{c}4 \\
(2,33)\end{array}$ & $\begin{array}{c}0.0 \\
(-1.3,0.0)\end{array}$ & $\begin{array}{c}20 \\
(15,23)\end{array}$ \\
\hline$\Delta s \mathrm{aO}_{2}(\%)$ & $\begin{array}{c}99.3 \\
(94.8,99.4)\end{array}$ & $\begin{array}{c}0.0 \\
(-1.7,0.0)\end{array}$ & $\begin{array}{c}68 \\
(10,98)\end{array}$ & $\begin{array}{c}0.0 \\
(0.0,0.0)\end{array}$ & - \\
\hline$\triangle \mathrm{ICP}(\mathrm{mm} \mathrm{Hg})$ & $\begin{array}{c}13.7 \\
(11.4,18.7)\end{array}$ & $\begin{array}{c}-0.6 \\
(-2.2,2.0)\end{array}$ & $\begin{array}{c}8 \\
(3,45)\end{array}$ & $\begin{array}{c}0.7 \\
(-1.7,4.2)\end{array}$ & $\begin{array}{c}13 \\
(8,42)\end{array}$ \\
\hline$\Delta \mathrm{CaBF} \dagger(\mathrm{mL} / \mathrm{min})$ & $\begin{array}{c}126.3 \\
(91.8,162.4)\end{array}$ & $\begin{array}{c}-12.4^{* *} \\
(-17.4,-8.3)\end{array}$ & $\begin{array}{c}5 \\
(4,7)\end{array}$ & $\begin{array}{c}1.6 \\
(0.0,5.8)\end{array}$ & $\begin{array}{c}63 \\
(15,103)\end{array}$ \\
\hline$\Delta c \mathrm{O}_{2} \mathrm{Hb}(\mu \mathrm{mol} / 100 \mathrm{~g})$ & Not available & $\begin{array}{c}-0.14 \\
(-0.22,0.15)\end{array}$ & $\begin{array}{c}8 \\
(5,63)\end{array}$ & $\begin{array}{c}0.00 \\
(0.00,0.20)\end{array}$ & $\begin{array}{c}56 \\
(48,67)\end{array}$ \\
\hline$\Delta c \mathrm{HHb}(\mu \mathrm{mol} / 100 \mathrm{~g})$ & Not available & $\begin{array}{c}0.09^{*} \\
(0.00,0.20)\end{array}$ & $\begin{array}{c}10 \\
(6,31)\end{array}$ & $\begin{array}{c}0.00 \\
(-0.15,0.00)\end{array}$ & $\begin{array}{c}50 \\
(17,59)\end{array}$ \\
\hline$\Delta \mathrm{CBV}(\mathrm{mL} / 100 \mathrm{~g})$ & Not available & $\begin{array}{c}-0.08 \\
(-0.16,0.16)\end{array}$ & $\begin{array}{c}12 \\
(5,82)\end{array}$ & $\begin{array}{c}0.00 \\
(0.00,0.07)\end{array}$ & $\begin{array}{c}41 \\
(17,58)\end{array}$ \\
\hline
\end{tabular}

Values are median (range).

${ }^{*} p<0.01$.

${ }^{* *} p<0.001$.

$\dagger n=10$.

is some evidence that the autoregulatory response after blood pressure change occurs with a delay of a few seconds (22). Due to decreased $\mathrm{CBF}, \mathrm{O}_{2}$ supply to the brain will be reduced, as reflected by decreased $c \mathrm{O}_{2} \mathrm{Hb}$. This will be compensated for by increased $\mathrm{O}_{2}$ extraction, as reflected by the initial increase of $c \mathrm{HHb}$, as well as by arteriolar vasodilatation, as reflected by the secondary increase of $\mathrm{CBV}$ and the delayed increase of ICP. The secondary increase of $\mathrm{cO}_{2} \mathrm{Hb}$, which occurred later than $\mathrm{CBV}$ increase, can be explained by the return of oxygenated blood to the dilated cerebral vascular bed after closing the bridge. This will also result in decreased $\mathrm{O}_{2}$ extraction, as reflected by the secondary decrease of $c \mathrm{HHb}$. The initial increase of $c \mathrm{HHb}$ could also be explained by decreased cerebral venous outflow, because CVP is increased due to relative obstruction of venous blood flow in the venous tubing by arterial-venous shunting of blood through the bridge. However, occurrence of retrograde flow of arterial blood through the venous tubing to the right atrium cannot be excluded. Further investigation is needed to clarify the flow changes in each part of the circuit during opening of the bypass bridge.

The lack of biphasic responses in the newborn infants might be caused by decrease of vascular reactivity due to vasoactive agents, which are usually used before starting ECMO. In the piglets these agents were not used, permitting complete contraregulation after closing the bridge.

As the piglet lungs were normal, the animals were able to maintain $\mathrm{saO}_{2}$, despite a significant reduction of oxygenated blood supply during opening of the bypass bridge. In contrast, the poor pulmonary function of the infants results in inability to maintain $\mathrm{saO}_{2}$ during opening of the bridge. This normally will result in 


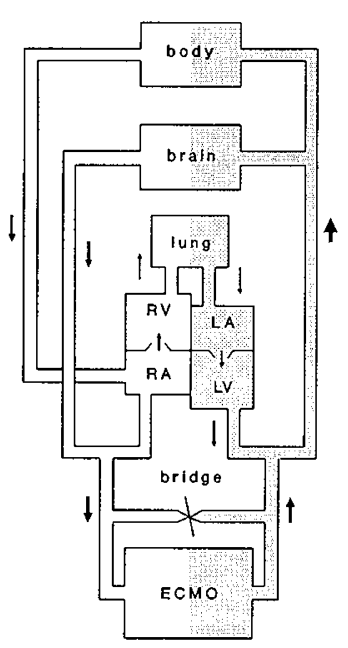

A

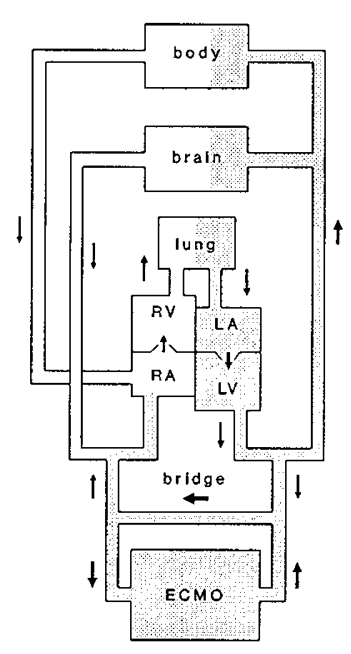

B

$$
\begin{aligned}
& \text { high } \mathrm{O}_{2} \text { saturation } \\
& \text { intermediate } \mathrm{O}_{2} \text { saturation } \\
& \text { low } \mathrm{O}_{2} \text { saturation }
\end{aligned}
$$

Figure 3. Schematic model of blood flow direction and oxygenation during ECMO in respiratory distressed newborn with closed bypass bridge $(A)$ and presumed changes when the bridge is open $(B) . \mathrm{RA}=$ right atrium, LA $=$ left atrium, $\mathrm{RV}=$ right ventricle, $\mathrm{LV}=$ left ventricle.

decrease of cerebral vascular resistance and consequently increase in $\mathrm{CBV}$, which might compensate for the $\mathrm{CBV}$ decrease caused by reduction of MABP and explain the less clear effect of bridge opening on CBV in the infants.

The clinical relevance of our findings is unclear, because this is the first report showing evident changes in cerebral circulation and $\mathrm{O}_{2}$ supply due to bridge opening. It might be harmful for the brain, but this is not supported by the finding of unchanged $c$ Cyt.aa ${ }_{3}$, reflecting unaffected cerebral $\mathrm{O}_{2}$ availability. However, data on $c$ Cyt.aa ${ }_{3}$ should be interpreted with caution, inasmuch as the value was calculated using an algorithm that is derived from experiments on rat brains after exchange transfusion with fluorocarbon, and therefore results might be affected by noise due to residual $\mathrm{Hb}$ after fluorocarbon exchange (19), as well as due to scattering by fluorocarbon which is different from that of erythrocytes. During an average ECMO run of 120 -h duration (2), the bridge will opened manually approximately 480 times with variable duration. It can be speculated that this frequently repeated perturbation of the cerebral circulation might be a risk factor for cerebrovascular injury, an important complication during $\operatorname{ECMO}(2,23)$ and a strong predictor of poor neurodevelopmental outcome (3).

As the bypass bridge is an essential part of the ECMO circuit, an alternative strategy for preventing clot formation should be looked for. An adjustable valve in the bridge allowing a very low but continuous blood flow through the bridge could be designed. Another future option would be the design of a one-way valve in different parts of the ECMO circuit. However, it is not known whether the presence of such valves would result in local turbulence facilitating thrombus formation.

In conclusion, significant changes in cerebral oxygenation and hemodynamics were observed during opening of the bypass bridge during ECMO. The clinical relevance is unclear, but these frequently recurring changes may contribute to cere-

brovascular injury during ECMO. Further study is necessary to determine the best management of the bypass bridge during ECMO.

Acknowledgments. The authors thank the nursing staff of the neonatal intensive care unit, the staff of the Animal Laboratory, and all members of the ECMO Research Group for their contribution to this study. We are also grateful to M. Gerritse for assistance in data analysis, J. Evers for technical support, and S. Houston for linguistic support.

\section{REFERENCES}

1. Short BL, Miller MK, Anderson KD 1987 Extracorporeal membrane oxygenation in the management of respiratory failure in the newborn. Clin Perinatol 14:737-748

2. Stolar CJH, Snedecor SM, Bartlett RH 1991 Extracorporeal membrane oxygenation and neonatal respiratory failure: Experience from the Extracorporeal Life Support Organization. J Pediatr Surg 26:563-571

3. Glass P 1993 Patient neurodevelopmental outcomes after neonatal ECMO. In: Arensman RM, Cornish JD (eds) Extracorporeal Life Support. Blackwell Scientific Publications, Boston, pp 241-251

4. Wildin SR, Landry SH, Zwischenberger JB 1994 Prospective, controlled study of developmental outcome in survivors of extracorporeal membrane oxygenation: The first 24 months. Pediatrics 93:404-408

5. Heiss KF, Bartlett RH 1989 Extracorporeal membrane oxygenation: An experimental protocol becomes a clinical service. Adv Pediatr 36:117-136

6. Zwischenberger JB, Cox CS 1993 Emergencies during extracorporeal membrane oxygenation and their management. In: Arensman RM, Cornish JD (eds) Extracorporeal Life Support. Blackwell Scientific Publications, Boston, pp 207-225

7. Glauser EM 1966 Advantages of piglets as experimental animals in pediatric research. Exp Med Surg 24:181-190

8. Van Bel F, Roman C, Klautz RJM, Teitel DF, Rudolph AM 1994 Relationship between brain blood flow and carotid arterial flow in the sheep fetus. Pediatr Res 35:329-333

9. Thomiley MS, Livera LN, Wickramasinghe YABD, Spencer SA, Rolfe P 1990 The non-invasive monitoring of cerebral tissue oxygenation. Adv Exp Med Biol 277:323-334

10. Jöbsis FF 1977 Noninvasive infrared monitoring of cerebral and myocardial oxygen sufficiency and circulatory parameters. Science 198:1264-1267

11. Liem KD, Hopman JCW, Kollée LAA, Oeseburg B 1994 Effects of repeated indomethacin administration on cerebral oxygenation and haemodynamics in preterm infants: combined near infrared spectrophotometry and Doppler ultrasound study [published erratum appears in Eur J Pediatr 1994;153:728]. Eur J Pediatr 153:504-509

12. Liem KD, Oeseburg B, Hopman JCW 1992 Method for the fixation of optrodes in near infrared spectrophotometry. Med Biol Eng Comput 30:120-121

13. Van der Zee P, Cope M, Arridge SR, Essenpreis M, Potter LA, Edwards AD, Wyat JS, McCormick DC, Roth SC, Reynolds EOR, Delpy DT 1992 Experimentally measured optical pathlengths for the adult head, calf and forearm and the head of the newborn infant as a function of inter optode spacing. Adv Exp Med Biol 316:143-153

14. Wyatt JS, Cope M, Delpy DT, van der Zee P, Arridge S, Edwards AD, Reynolds EOR 1990 Measurement of optical pathlength for cerebral near-infrared spectroscopy in newborn infants. Dev Neurosci 12:140-144

15. Wickramasinghe Y, Rolfe P 1993 Modified NIR coefficients taking into account the wavelength dependence of optical pathlength. In: J. Bancroft (ed) Newsletter EC Concerted Action Near Infrared Spectrophotometry and Imaging of Biological Tissues, Issue 2. Stoke on Trent, UK, p 5

16. Jöbsis-Vandervliet FF 1991 Near infrared monitoring of cerebral cytochrome $c$ oxidase: Past and present (and future?). In: Lafeber HN, Aarnoudse JG, Jongsma HW (eds) Fetal and Neonatal Physiological Measurements. Proceedings of the 4th International Conference on Fetal and Neonatal Physiological Measurements. Elsevier Science Publishers, Amsterdam, pp 41-55

17. Lammertsma AA, Brooks DJ, Beaney RP, Turton DR, Kensett MJ, Heather JD, Marshall J, Jones T 1984 In vivo measurement of regional cerebral haematocrit using positron emission tomography. J Cereb Blood Flow Metab 4:317-322

18. Mchedlishvili G 1986 Arterial Behaviour and Blood Circulation in the Brain. Plenum Press, New York, pp 56-71

19. Pryds O, Greisen G, Skov LL, Friis-Hansen B 1990 Carbon dioxide-related changes in cerebral blood volume and cerebral blood flow in mechanically ventilated preterm neonates: comparison of near infrared spectrophotometry and ${ }^{133}$ xenon clearance. Pediatr Res 27:445 449

20. Liem KD, Hopman JCW, Kollée LAA, Oeseburg B 1992 Assessment of cerebral oxygenation and hemodynamics by near infrared spectrophotometry during induction of ECMO: Preliminary results. Adv Exp Med Biol 317:841-846

21. Short BL, Walker LK, Bender KS, Traystman RJ 1993 Impairment of cerebral autoregulation during extracorporeal membrane oxygenation in newborn lambs. Pediatr Res 33:289-294

22. Kontos HA, Wei EP, Navari RM, Levasseur JE, Rosenblum WI, Patterson JL 1978 Responses of cerebral arteries and arterioles to acute hypotension and hypertension. Am J Physiol 234:H371-H383

23. Taylor GA, Short BL, Fitz CR 1989 Imaging of cerebrovascular injury in infants treated with extracorporeal membrane oxygenation. J Pediatr 114:635-639 